thetase inhibitors but tend to cause more side effects. Tranexamic acid is probably the best; 1.0 or $1.5 \mathrm{~g}$ is given six hourly during heavy bleeding. ${ }^{131617}$ It is especially suitable for patients with bleeding disorders. Aminocaproic acid is less convenient to take, less effective, and more likely to cause side effects. ${ }^{10} 17-20$

Ethamsylate has a direct action on capillaries, and several workers have shown that it reduces menstrual loss. ${ }^{21}$ Kasonde and Bonnar, however, found it to be of no value in women with haemorrhage associated with intrauterine contraceptive devices. ${ }^{22}$

Danazol depresses the secretion of gonadotrophins and sex steroids but possesses some anabolic and weakly androgenic properties. In a dose of $200 \mathrm{mg}$ daily it reduces menstrual loss and raises haemoglobin concentrations. Patients may be treated for three months and benefit may continue for a further three months. ${ }^{23}$ Danazol may, however, potentiate anticoagulants such as warfarin ${ }^{24}$ and cause gain in weight and possibly hirsutism. Its use should, therefore, probably be confined to women with severe symptoms who fail to respond to other treatments and are unwilling to undergo surgery.

Ergot alkaloids are of no value in treating menorrhagia, ${ }^{10}$ and irradiation —once a legitimate alternative to surgery-is also now obsolete. (Side effects include a slightly increased risk of developing malignant disease, ${ }^{25}$ and symptoms due to lack of oestrogen.)

Prostaglandin synthetase inhibitors, tranexamic acid, and ethamsylate have proved to be the most useful drugs in the conservative management of menorrhagia (not due to intrauterine contraceptive devices), and further well designed comparative studies are needed to establish their relative merits.

Consultant Gynaecologist, Royal Hampshire County Hospital,

Winchester SO22 5DG

1 Richards DH. Depression after hysterectomy. Lancet 1973;ii:430-2.

2 Richards DH. A post hysterectomy syndrome. Lancet 1974; ii $983-5$.

3 Barker MG. Psychiatric illness after hysterectomy. Br Med F 1968;ii:91-5.

4 Meikle S. The psychological effects of hysterectomy. Canadian Psychological Reviews 1977;18: 128-41.

5 Gath D, Cooper P, Day A. Hysterectomy and psychiatric disorder: I. Levels of psychiatric morbidity before and after hysterectomy. Br $\mathcal{F}$ Psychiatry 1982;140:335-50.

6 Coppen A, Bishop M, Beard RJ, Barnard GJR, Collins WP. Hysterectomy, hormones, and behaviour. Lancet 1981;i:126-8.

behaviour. Lancet 1981;i:126-8.
Nilsson L, Rygo G. Treatment of menorrhagia with epsilon aminocaproic acid. Acta Obstet

Gynecol Scand 1965;44:467-73.
Nilsson L, Rygo G. Treatment

Carr C. Results of conservative treatment of dysfunctional uterine bleeding in the fifth decade of life. Fournal of Obstetrics and Gynaecology of the British Commonwealth 1966;73:828-31.

9 Nilsson L, Rybo G. Treatment of menorrhagia. Am 7 Obstet Gynecol 1971;110:713-20.

10 Goldrath MH, Fuller TA, Segal S. Laser photovaporization of endometrium for the treatment of menorrhagia. Am $\mathcal{F}$ Obstet Gynecol 1981;140:14-9.

1 Bishop P, di Almeida JCC. Treatment of menstrual disorders. BrMed f 1960;ii: 1103-5.

12 Elder MG. Prostaglandins and menstrual disorders. Br Med $\mathcal{J}$ 1983;287:703-4

13 Ylikorkala $\mathrm{O}$, Viinikka $\mathrm{L}$. Comparison between antifibrinolytic and antiprostaglandin treatment in reduction of increased menstrual loss associated with IUCD's. Br f Obstet Gynaecol 1983;90:
$78-83$.

14 Ylikorkala O, Kaupilla A, Sitjander M. Antiprostaglandin therapy in prevention of side effects of intrauterine contraceptive devices. Lancet 1978;ii:393-4.

15 Hayne PJ, Flint APF, Hodgson H, et al. Studies in menorrhagia. (a) Mefenamic acid (b) endometrial prostaglandin concentrations. Int f Gynaecol Obstet 1980;17:567-72.

metrial prostaglandin concentrations. Int Gynaecol Obstet $1980 ; 17: 567-72$.
Nilsson L, Rybo G. Treatment of menorrhagia with antifibrinolytic agent, tranexamic acid. Acta Obstet Gynecol Scand 1967;46:572-80.
.

17 Bonnar RJ, Gillebaud J, Kasonde JM, Sheppard BL. Clinical applications of fibrinolytic inhibition in gynaecology. F Clin Pathol 1980;33:55-9.

18 Nilsson L, Bjorkman S. Experiences with epsilon aminocaproic acid in the treatment of profuse menorrhagia. Acta Med Scand 1965;177:445-57.

19 Vermylen J, Verhaegen-Dechereq ML, Verstratte M, Fierans FA. Double blind study of the effect of tranexamic acid in essential menorrhagia. Thrombosis et Diathesis Haemorrhagica 1968 20:583-7.

20 Kasonde JM, Bonnar RJ. Epsilon aminocaproic acid and menstrual loss in women with intrauterine contraceptive devices. Br Med J 1975;iv: 17-9.

21 Harrison RF, Campbell S. A double blind trial of ethamsylate in the treatment of primary and intrauterine contraceptive devices menorrhagia. Lancet 1976;ii:283-5.

2 Kasonde JM, Bonnar RJ. Effects of ethamsylate and epsilon aminocaproic acid in menstrual blood loss in women with intrauterine contraceptive device. Br Med f 1975; iv:21-2.

23 Chimbira TH, Anderson ABM, Cope E, Turnbull AC. Reduction of menstrual blood loss by danazol in unexplained menorrhagia: lack of effect of placebo. Br f Obstet Gynaecol 1980;87. $1152-8$.

24 Small M, Peterkin M, Lowe DGO, et al. Danazol and oral anticoagulants. Scott Med F 1982;27: $331-2$

25 Doll $\mathrm{R}$, Smith $\mathrm{R}$. Long term effects of $\mathrm{x}$ irradiation in patients treated for metropathia haemorrhagica. Br f Radiol 1968;4:362-8

\section{Haemolysis in childhood}

The causes and frequency of haemolysis in childhood vary according to age. In the neonatal period haemolysis is invariable; it may be physiological or pathological. Physiological haemolysis-destruction of red cells-is never more intense than in the haemolysis of fetal red cells just after birth, almost halving the initial circulating haemoglobin concentration by the time of resumption of erythropoiesis at about seven weeks after full term delivery. "Physiological" jaundice, resulting from this haemoglobin catabolism, is exaggerated to hyperbilirubinaemia in term babies by fetal and neonatal diseases, maternal disorders, or a combination of these. ${ }^{1}$ When there is a history of maternal smoking ${ }^{2}$ or administration of oxytocin the effects may be mediated through impairments in the baby's red cell deformability, though the effects of oxytocin are controversial. ${ }^{3}$ Preterm infants are more at risk of haemolytic jaundice, ${ }^{1}$ not only because of hepatic functional immaturity but also because of their greater dependence at birth on mainly fetal red cells, whose viability is reduced for both functional and metabolic reasons. ${ }^{4}$

Pathological haemolysis-haemolytic anaemia-is never more common than in the neonatal period. ${ }^{5}$ Underlying this may be intrinsic abnormalities of the red cell's membrane such as hereditary spherocytosis, enzymopathies such as deficiency of glucose-6-phosphate dehydrogenase, or, rarely, even haemoglobinopathies such as homozygous sickle cell disease (though since this is a $\beta$ globin chain abnormality it usually causes little haemolysis before the second month of life). ${ }^{6}$ Such haematological diagnoses of inherited red cell abnormalities may be made more confidently from the age of 3 months.

In white people, however, the most common cause of neonatal haemolytic anaemia is still fetomaternal isoimmunisation. Antirhesus ( $R h) \mathrm{D}$ prophylaxis has reduced fetomaternal immunisation by almost $90 \%$; in 1968 there were 750 stillbirths and infant deaths from $\mathrm{Rh}(\mathrm{D})$ haemolytic disease of the newborn, compared with 123 10 years later. Failure of anti-D prophylaxis may result from antenatal immunisation, inadvertent omission, or inadequate dosage. ${ }^{7}$ Antenatal anti-D prophylaxis may reduce maternal immunisation even further though the cost effectiveness of this remains controversial. ${ }^{8}$ With the success of anti-D prophylaxis, other antibodies are now becoming relatively more important. ${ }^{9}$ Any antibody which crosses the placenta may cause haemolytic disease of the newborn. As yet no other prophylaxis against maternal immunisation is available. After birth, phototherapy, transfusion of red cells, and exchange transfusion are still the mainstays of treatment of haemolytic disease of the newborn. ${ }^{10}$

In older children acute autoimmune haemolytic anaemia causes haemoglobinuria and life threatening anaemia; acute autoimmune haemolytic anaemia is uncommon and so is unlikely to be seen more than a few times by any one haematologist or paediatrician, and their experience of treatment must be limited. The recent review by Sokol et al of 42 cases studied over the past 23 years at the Sheffield Regional Blood Transfusion Service, therefore, contains useful guidance in investigation, management, and prognosis of these rare but acutely worrying problems. ${ }^{11}$ Two thirds of the patients were children under 5 years old in whom the acute haemolysis usually occurred after trivial infections and was short lived. They recommend that steroids should be reserved for children suffering from persistent and severe haemolytic anaemia after two or three 
weeks' supportive care. Splenectomy may very occasionally become necessary after lapse to chronic haemolysis in three to six months. Pneumococcal vaccination and oral penicillin minimise but do not abolish the infective hazards of hyposplenism. ${ }^{12}$ They found, as did others, ${ }^{13}$ that autoimmune haemolysis in childhood is only rarely associated with underlying disease such as systemic lupus erythematosus. This contrasts with experience in adults, in whom autoimmune haemolytic anaemia may be symptomatic of collagen diseases such as systemic lupus erythematosus or of lymphoma. ${ }^{14}$ The enigmas of the pathogenesis of autoantibody formation to red cells will be important to unravel. This diathesis may be partly genetically determined. ${ }^{15}$

Recent progress has been made in the understanding and management of the haemolytic-uraemic syndrome, an uncommon but dramatic and life threatening emergency. ${ }^{16}$ Its pathogenesis is now thought in some cases to hinge on imbalance between prostacyclin and thromboxane and on platelet-vascular interactions and endothelial damage. With greater understanding of the pathological basis of the haemolytic-uraemic syndrome rational, specific management may soon become available, at least in some cases. Evaluation of any proposed specific treatments would have to be adequately controlled or doubts will remain about their value, as in the recent report of management of epidemic and sporadic haemolytic-uraemic syndrome using vitamin E. ${ }^{17}$ Improvements in recent years in supportive care, particularly for renal failure, have improved the prognosisespecially of the sporadic form of the syndrome.

The common ground in management of these haemolytic anaemias acquired in childhood, whether caused by autoantibody formation or associated with metabolic and microvascular damage, is recognition of the importance of supportive, symptomatic care. If the child's anaemia can be "tided over" for a week or two - and any associated disorder such as renal failure effectively managed - the only treatment needed may be red cell transfusions. More aggressive "haematological" treatments such as steroids, immunosuppression, or even splenectomy for immune mediated haemolysis are indicated only with lapse over several weeks or months to chronic, severe autoimmune haemolytic anaemia.

Consultant Neonatologist

BARBARA HOLLAND

Queen Mother's Hospital,

Glasgow G3 8SH

Senior Lecturer in Haematology,

C A J WARDROP

University of Wales College of Medicine,

Cardiff CF4 4XN

1 Maisels MJ. Neonatal jaundice. In: Avery GB, ed. Neonatology-pathophysiology and management of the newborn. Philadelphia: J B Lippincott, 1981:473-96.

2 Buchan PC. Cigarette smoking in pregnancy and fetal hyperviscosity. Br Med f 1983;286:1315.

Johnson JD, Aldrich $M$, Angelus $P$, et al. Oxytocin and neonatal hyperbilirubinemia. $A m \mathcal{F} D$ Child 1984;138: 1047-50.

4 Oski FA. The erythrocyte and its disorders. In: Nathan DG, Oski FA, eds. Hematology of infancy and childhood. Philadelphia: W B Saunders, 1981:17-49.

5 Walker W. Haemolytic anaemia in the newborn infant. Clinical Haematology 1975;4:145-66.

6 Anonymous. Sickle-cell anaemia in infancy [Editorial]. Br Med f 1978;i:1439-40.

7 DHSS: SMAC. Memorandum on haemolytic disease of the newborn-1976; Addendum-1981. London: DHSS. (DHSS Branch HSIA, Room 1206 Hannibal House, Elephant and Castle, London SE1 6TE.

8 Torrance GW, Zipursky A. Cost-effectiveness of antepartum prevention of $\mathrm{Rh}$ immunization. Clinics in Perinatology 1984;11:267-82.

9 Hardy J, Napier JAF. Red cell antibodies detected in antenatal tests on rhesus positive women in south and Mid Wales. Br f Obstet Gynaecol 1981;88:91-100.
10 Naiman JL. Erythroblastosis fetalis. In: Oski FA, Naiman JL, eds. Hematologic problems in the newborm. Philadelphia: W B Saunders, 1982:283-346.

1 Sokol RJ, Hewitt S, Stamps BK. Autoimmune haemolysis in childhood and adolescence. Acto Haematol 1984;72:245-57.

12 Ferguson A. Hazards of hyposplenism. Br Med f 1982;285:1375-6.

13 Heisel $M$, Ortega J. Factors influencing prognosis in childhood autoimmune hemolytic anemia Am F Pediatr Hematol Oncol 1983;5:147-52.

4 Pirofsky B. Immune haemolytic disease: the autoimmune haemolytic anaemias. Clinics in Haematology 1975; 4: 167-80.

15 Lippmann SM, Arnett FC, Conley CL, Ness PM, Meyers DA, Bias WB. Genetic factors predisposing to autoimmune diseases. Am $\mathcal{F}$ Med 1982;73:827-40.

6 Levin M, Barratt TM. Haemolytic uraemic syndrome. Arch Dis Child 1984;59:397-400.

17 Powell HR, McCredie DA, Taylor CM, Burke JR, Walker RG. Vitamin E treatment of Powell HR, McCredie DA, Taylor CM, Burke JR, Walker
haemolytic syndrome. Arch Dis Child 1984;59:401-4.

\section{A chamber pot and Bible}

Since 1981 seven young men have died of self inflicted injuries in the Glenochil complex in Scotland, which includes a detention centre and a young offenders institution, and at least three of them were deliberate suicides. After a fatal accident inquiry in 1984 into the death of William MacDonald, aged 17, who was found "hanging with a bedsheet round his neck in a half sitting position," the Secretary of State for Scotland, Mr George Younger, set up a working party to review suicide precautions at the complex.

The working party was chaired by an Edinburgh forensic psychiatrist, Dr Derek Chiswick, and in something of a hurry it has produced a radical document that has implications far beyond Glenochil. More information on the working party's 63 recommendations is given on $p 353$, but here we want to highlight the recommendation to abolish what is called "strict suicide observation." This observation is applied to inmates thought to be at risk of suicide. They are admitted to special cells in which all the washbasins, fitted furniture, and protruding fitments have been removed; an electric light, operable from the outside, burns all the time, and the room contains only a desk and chair made from toughened cardboard, a plastic chamber pot, a paperback book (or a comic), and a copy of the Bible. During the day the inmate has one blanket made of coarse, untearable canvas, and at night he is given another such blanket and a mattress; during the winter, staff and inmates agreed, the cells can be extremely cold. The inmate usually has to wear a canvas gown and is not allowed underclothing or any other clothes. He sits in his room all day, is observed every 15 minutes, and is not permitted any association with other inmates. In 1984, 164 inmates were placed on strict suicide observation for between two and 365 days, and four were there for more than nine months.

The working party describes this regimen as "inhumane and unacceptable," condemning the denial of human contact as "contrary to modern notions of psychiatric care." It has suggested instead a system more like that used in psychiatric hospitals that depends on human contact and team work from nurses, psychiatrists, and psychologists. The Secretary of State has accepted "in broad outline" the new system but has refused to abolish strict suicide observation on the grounds that such a move would have to be approached cautiously and examined for the whole prison system (adult as well as young offender). This seems to us not an argument for rejecting the recommendation for Glenochil but rather for applying it to the whole of the British prison system. 